\title{
Postglacial distribution area expansion of Polyommatus coridon (Lepidoptera: Lycaenidae) from its Ponto-Mediterranean glacial refugium
}

\author{
T Schmitt and A Seitz \\ Institut für Zoologie, Abt. V Ökologie, Saarstraße 21, 55099 Mainz, Germany
}

The genetic population structure of Polyommatus coridon (Poda, 1761) (Chalk-hill blue) was studied by means of allozyme electrophoresis in north-eastern Germany, the Czech Republic, Slovakia and Hungary. All analysed parameters showed high genetic diversity within populations (number of alleles: 2.61; observed and expected heterozygosity: $18.6 \%$ and $19.7 \%$, respectively; percentage of polymorphic loci: total: $73.6 \%$, on $95 \%$ level: $56.1 \%$ ), whereas genetic differentiation between populations was comparatively low $\left(\mathrm{F}_{\mathrm{ST}}=\right.$ $0.028 \pm 0.005$ s.d.). Hierarchical variance analysis revealed significant structuring among five regional population clusters. A significant isolation-by-distance structure exists $(r=$ $0.39 ; P<0.05)$. The mean number of alleles per locus declined significantly from south to north and showed a strong correlation with the geographical latitude $(r=-0.88$, $P<0.0001)$. We suggest that this reflects the loss of alleles during the postglacial colonisation of eastern Central Europe from an ice-age refugium in the Balkans. A possible scenario for the postglacial expansion process in eastern Central Europe is discussed using these data: coming from the northwestern part of the Balkans, $P$. coridon may have reached the western tip of Hungary, and consecutively colonised eastern Central Europe using two alternative expansion routes.

Heredity (2002) 89, 20-26. doi:10.1038/sj.hdy.6800087

Keywords: genetic population structure; allozyme electrophoresis; postglacial colonisation; Porta Hungarica; Moravian Gap; isolation-by-distance; butterflies

\section{Introduction}

Many thermophilic species were restricted to refugia in southern Europe during the last ice-ages (eg, Hewitt, 1996, 1999; Taberlet et al, 1998). In a previous work, we deduce the glacial isolation of Polyommatus coridon (Poda, 1761) (Chalk-hill blue) in two Mediterranean refugia: the Italian peninsula and the Balkans (Schmitt and Seitz, 2001a). This isolation apparently resulted in two well differentiated genetic lineages. For the western lineage, we previously analysed the postglacial expansion of the distribution area and pointed out possible corridors through which spread was possible into Western and western Central Europe (Schmitt et al, 2002).

For the eastern lineage, few data are available in the literature. None of the existing studies, dealing with allozyme analyses of $P$. coridon, included eastern populations (Mensi et al, 1988; Lelièvre, 1992; Marchi et al, 1996). The number of chromosomes was studied only in the Balkans (de Lesse, 1969).

The eastern lineage of $P$. coridon is distributed in the east as far as the steppes north of the Lake Caspi (Korschunov and Gorbunov, 1995). In the south, it reaches northern and central Greece (Pamperis, 1997), but

Correspondence: Dr T Schmitt, Institut für Biogeographie, Fachbereich VI, Geozentrum Gebäude H 857, D - 54286 Trier, Germany. E-mail: thsh@uni-trier.de

Received 21 September 2001; accepted 4 March 2002 is absent from Turkey (Hesselbarth et al, 1995). In Poland, P. coridon reaches the Baltic Sea (Buszko, 1997). In eastern Germany, the most northern populations are in northeastern Brandenburg (Reinhardt, 1983). In the west, this lineage comes into contact with the western $P$. coridon lineage. Combining genetic and morphological studies, the boundary between both genetic lineages was found to be in eastern Thuringia. In the south, it follows the CzechGerman and the Austrian-German border. In the Alps, the regions draining to the east are populated by the eastern lineage. The border between Slovenia and Italy represents the western limit south of the Alps (Schmitt and Seitz, 2001a). European distribution limits and the probable contact zone with the western lineage are shown in Figure 1.

This paper contributes to a better understanding of the postglacial distribution changes, the population structure and the genetic composition of the eastern lineage of $P$. coridon.

\section{Materials and methods}

A total of 743 butterflies was collected at 18 localities (see Figure 1), and stored in liquid nitrogen immediately after being captured until electrophoretic analysis was carried out. Furthermore, the density of the $P$. coridon population and the habitat size was assessed for each sampling site, and hereby, the total populations size was roughly estimated. 


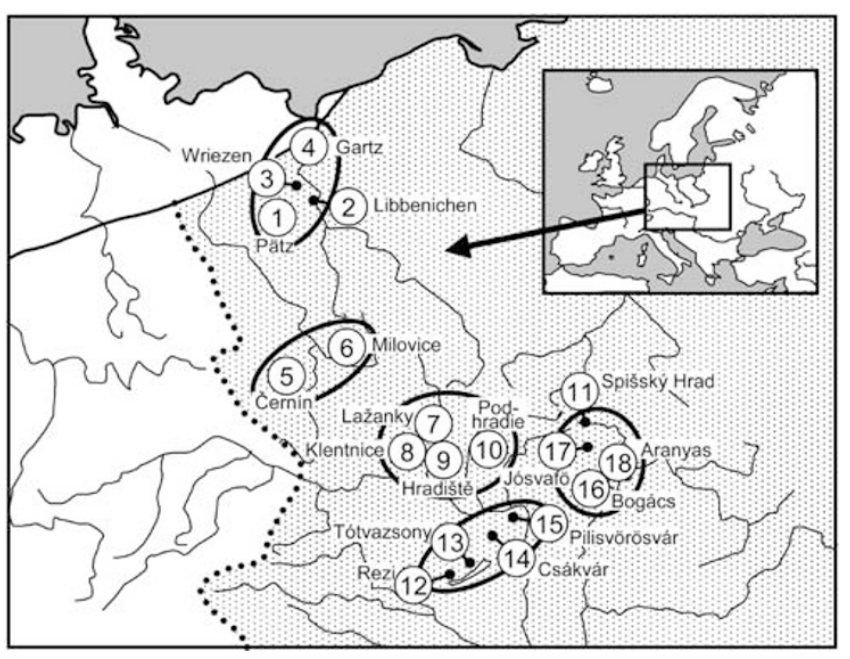

Figure 1 Sampling localities of Polyommatus coridon. Sample numbers correspond to Table 2. The species' northern distribution limit (Tolman and Lewington, 1998) is marked as a solid line, the probable border between the eastern and the western lineage conforming phenotypic differentiation (Schmitt and Seitz, 2001a) is shown as a dotted line, and the distribution range of the eastern lineage of P. coridon (Tolman and Lewington, 1998) is indicated by a dotted area.

Allozyme electrophoresis of twenty loci was performed using standard protocols (eg, Richardson et al, 1986; Hebert and Beaton, 1993). Details on enzymes and running conditions are described in Schmitt and Seitz (2001b). The discrimination between some alleles of Ldh was not always possible. Therefore, the results for this enzyme were excluded from all calculations of genetic distances and identities and from all further calculations based on these values.

All loci showed banding patterns consistent with known quaternary structures and with autosomal inheritance (Richardson et al, 1986) except for 6Pgdh which is located on the Z-chromosome (see Schmitt and Seitz, 2001a). The alleles were labelled conforming their relative mobility.

The allele frequencies, F-statistics (Weir and Cockerham, 1984), Nei's standard genetic distances (Nei, 1978) and RxC tests (Sokal and Rohlf, 1995) were calculated with G-Stat (Siegismund, 1993). Hierarchical variance analysis was done with Arlequin 2.000 (Schneider et al, 2000). Hardy-Weinberg equilibrium (Louis and Dempster, 1987), genetic disequilibrium (Weir, 1991), exact tests for differentiation (Raymond and Rousset, 1995a) and Mantel tests (1967) were performed with GENEPOP (Raymond and Rousset, 1995b). Spatial autocorrelation was analysed with Le Progliciel R 4.0d3 (Casgrain and Legendre, 2001). Un-rooted cluster analyses were done with PHYLIP (Felsenstein, 1993). We used the neighbour joining (Saitou and Nei, 1987) and the UPGMA method. Differences between means were tested by two-tailed Utests and sign-tests using STATISTICA (Stat Soft, 1993).

\section{Results}

Population sizes

Most of the populations studied had largely similar numbers of individuals (see Table 1). Only two populations
Table 1 Density of the Polyommatus coridon populations studied, size of their habitat and estimated total number of individuals

\begin{tabular}{|c|c|c|c|c|}
\hline & & Density & $\begin{array}{l}\text { Area } \\
\text { (ha) }\end{array}$ & $\begin{array}{c}\text { Total no. } \\
\text { of individuals }\end{array}$ \\
\hline Pätz & G-BB & $\mathrm{m}-\mathrm{h}$ & $5-10$ & $200-1.000$ \\
\hline Libbenichen & G-BB & $\mathrm{m}$ & $\sim 100$ & $>1.000$ \\
\hline Wriezen & G-BB & $\mathrm{m}$ & $>100$ & $>1.000$ \\
\hline Gartz & G-BB & 1 & $>100$ & $\sim 1.000$ \\
\hline Černín & CZ-B & $\mathrm{m}-\mathrm{h}$ & $2-5$ & $\sim 1.000$ \\
\hline Milovice & CZ-B & $1-\mathrm{m}$ & $>100$ & $>1.000$ \\
\hline Lažanky & CZ-M & $\mathrm{h}$ & $\sim 2$ & 200-1.000 \\
\hline Klentnice & CZ-M & $1-\mathrm{m}$ & $\sim 100$ & $\sim 1.000$ \\
\hline Hradiště & SK-SW & $\mathrm{h}$ & $\sim 100$ & $>10.000$ \\
\hline Podhradie & SK-SW & 1 & $\sim 100$ & $\sim 1.000$ \\
\hline Spišsky Hrad & SK-E & $1-\mathrm{h}$ & $\sim 50$ & $>1.000$ \\
\hline Rezi & $\mathrm{H}-\mathrm{W}$ & $\mathrm{m}$ & $\sim 50$ & $>1.000$ \\
\hline Tótvazsony & $\mathrm{H}-\mathrm{W}$ & $\mathrm{m}-\mathrm{h}$ & $>100$ & $>10.000$ \\
\hline Cszákvár & $\mathrm{H}-\mathrm{W}$ & $\mathrm{m}-\mathrm{h}$ & $>100$ & $>10.000$ \\
\hline Pilisvörösvar & $\mathrm{H}-\mathrm{W}$ & 1 & $\sim 100$ & $\sim 1.000$ \\
\hline Bogács & H-NE & $\mathrm{h}$ & $\sim 10$ & $>1.000$ \\
\hline Jósvafö & H-NE & 1 & $>100$ & $>1.000$ \\
\hline Aranyas & H-NE & 1 & $>100$ & $>1.000$ \\
\hline
\end{tabular}

The density was calculated using three density classes (1: low, $\sim 10$ individuals/ha; m: medium, $\sim 50$ individuals/ha; h: high, $\geq 100$ individuals/ha, locally even reaching densities of 1.000 and more individuals per ha). For abbreviations of regions (column 2) see Figure 2.

were particularly small (Pätz, Lažanky) and three populations particularly big (Hradiště, Tótvazsony, Csákvár). The population size of all the others was about 1000 . Fourteen of the habitat areas were fairly large (ie, at least 50 ha). The remaining four habitats (Pätz, Černín, Lažanky, Bogács) were between two and 10 ha. Populations of high and low densities were randomly distributed over the whole study area.

\section{Genetic variability}

All 20 loci were polymorphic in at least two of the 18 populations. The maximum number of distinguishable alleles was 12 in Pgi; while in Apk, only two alleles were detected. The mean number of alleles per locus for all populations was 6.8 ( \pm 2.9 s.d.). All allele frequencies are available on request from the authors.

The average number of alleles detected per locus per population showed a mean of 2.61 ( \pm 0.34 s.d.), ranging from 1.9 to 3.2. The percentage of polymorphic loci ranged from $55 \%$ to $85 \%$ with a mean of $73.6 \%( \pm 8.7$ s.d.). Applying the $95 \%$ criterion, the mean number of polymorphic loci was $56.1 \%$ ( \pm 5.8 s.d.), and ranged from $45 \%$ to $65 \%$. The high percentage of polymorphic loci coincided with high observed heterozygosities, ranging from $15.7 \%$ to $20.6 \%$, with a mean of $18.6 \%$ ( \pm 1.3 s.d.). Expected heterozygosity (19.7\% ( \pm 1.5 s.d.), ranging from $16.2 \%$ to $21.9 \%$ ) was marginally but significantly higher (sign test: $P=0.0095$ ). All data are presented in more detail in Table 2.

Hardy-Weinberg equilibrium and linkage disequilibrium No significant deviation from Hardy-Weinberg equilibrium was observed for any of the populations or loci. No significant linkage disequilibrium was found after applying the Bonferroni correction. Therefore, further analyses were performed applying standard methods of population genetics. 
Table 2 Average number of alleles per locus $(\mathrm{A})$, expected $\left(\mathrm{H}_{\mathrm{e}}\right)$ and observed heterozygosity $\left(\mathrm{H}_{\mathrm{o}}\right)$, total polymorphic loci $\left(\mathrm{P}_{\text {tot }}\right)$ and on $95 \%$-level $\left(\mathrm{P}_{95}\right)$ for all analysed samples of eastern European Polyommatus coridon

\begin{tabular}{|c|c|c|c|c|c|c|c|c|c|c|c|c|c|c|c|c|c|c|}
\hline & $\begin{array}{l}1 G \\
\text { Pätz }\end{array}$ & $\begin{array}{l}2 G \\
\text { Libbe }\end{array}$ & $\begin{array}{c}3 G \\
\text { Wriez }\end{array}$ & $\begin{array}{c}4 G \\
\text { Gartz }\end{array}$ & $\begin{array}{l}5 \mathrm{CZ} \\
\text { Černín }\end{array}$ & $\begin{array}{l}6 \mathrm{CZ} \\
\text { Milov }\end{array}$ & $\begin{array}{l}7 \mathrm{CZ} \\
\text { Lažan }\end{array}$ & $\begin{array}{l}8 \mathrm{CZ} \\
\text { Klent }\end{array}$ & $\begin{array}{c}9 S K \\
\text { Hradiš }\end{array}$ & $\begin{array}{l}10 S K \\
\text { Podhr }\end{array}$ & $\begin{array}{l}11 \text { SK } \\
\text { Spišsk }\end{array}$ & $\begin{array}{l}12 \mathrm{H} \\
\text { Rezi }\end{array}$ & $\begin{array}{c}13 \mathrm{H} \\
\text { Tótvaz }\end{array}$ & $\begin{array}{l}14 \mathrm{H} \\
\text { Czákv }\end{array}$ & $\begin{array}{l}15 \mathrm{H} \\
\text { Pilis }\end{array}$ & $\begin{array}{l}16 \mathrm{H} \\
\text { Bogác }\end{array}$ & $\begin{array}{l}17 \mathrm{H} \\
\text { Jósva }\end{array}$ & $\begin{array}{l}18 \mathrm{H} \\
\text { Arany }\end{array}$ \\
\hline A & 2.000 & 2.350 & 2.400 & 1.900 & 2.400 & 2.550 & 2.550 & 2.750 & 2.800 & 2.450 & 2.400 & 2.900 & 3.150 & 2.900 & 3.000 & 2.900 & 2.750 & 2.800 \\
\hline $\mathrm{H}_{\mathrm{e}}$ & 0.195 & 0.198 & 0.162 & 0.170 & 0.193 & 0.202 & 0.197 & 0.219 & 0.184 & 0.218 & 0.191 & 0.207 & 0.218 & 0.185 & 0.207 & 0.201 & 0.190 & 0.203 \\
\hline $\mathrm{H}_{\mathrm{o}}$ & 0.199 & 0.184 & 0.157 & 0.161 & 0.174 & 0.195 & 0.190 & 0.189 & 0.196 & 0.199 & 0.185 & 0.206 & 0.195 & 0.188 & 0.200 & 0.181 & 0.181 & 0.197 \\
\hline$P_{\text {tot }}$ & 0.550 & 0.800 & 0.750 & 0.550 & 0.700 & 0.700 & 0.800 & 0.750 & 0.800 & 0.800 & 0.650 & 0.750 & 0.850 & 0.750 & 0.800 & 0.800 & 0.800 & 0.650 \\
\hline $\mathrm{P}_{95}$ & 0.550 & 0.650 & 0.450 & 0.500 & 0.550 & 0.650 & 0.500 & 0.650 & 0.600 & 0.600 & 0.500 & 0.600 & 0.550 & 0.550 & 0.550 & 0.550 & 0.500 & 0.600 \\
\hline$n$ & 48 & 40 & 40 & 33 & 45 & 50 & 40 & 47 & 45 & 36 & 50 & 40 & 40 & 40 & 39 & 40 & 31 & 39 \\
\hline capt & 07 & 07 & 08 & 08 & 23 & 22 & 20 & 10 & 11 & 11 & 17 & 12 & 12 & 13 & 14 & 15 & 15 & $16 / 17$ \\
\hline
\end{tabular}

$n$ = sample size; names of sampling localities are abbreviated. capt $=$ day of capture in August 1997

\section{Regional structuring}

Applying an exact test for differentiation, the allelic differentiation between samples was highly significant for all loci after Bonferroni correction $(P<0.0001)$. The genetic distances (Nei, 1978) among samples ranged from 0.015 (Hradiště, south-western Slovakia and Bogács, north-eastern Hungary) to 0.037 (Pätz, Brandenburg and Bogács, north-eastern Hungary). The mean genetic distance between populations was 0.022 ( \pm 0.003 s.d.). $F_{\mathrm{ST}}$ $(0.028 \pm 0.005$ s.d. $)$ and $F_{\text {IS }}(0.037 \pm 0.013$ s.d. $)$ differed significantly from zero. The total genetic variance was 1.883. Hierarchical analysis discriminating the five geographic population clusters (see Figure 1) revealed 22.4\% of the among populations variance between these five groups.

The un-rooted cluster analyses, worked out with the neighbour-joining and the UPGMA method, revealed similar results. The populations from Hungary clustered predominantly together. The majority of populations from Czech Republic, Slovakia and Brandenburg formed a second cluster. The genetic distances of the Hungarian populations were greatest to the four populations from Brandenburg, especially to the population from Pätz. The neighbour-joining phenogram is shown in Figure 2.

Hierarchical variance analysis supported the topology of the neighbour joining tree: an analysis testing the western group (western Slovakia, Czech Republic, Brandenburg) against the eastern group (Hungary, eastern Slovakia) revealed $18.7 \%(P=0.019)$ of the between populations variance between these two groups. Within both of these groups, the variance between their internal geographical clusters was not significantly different from zero (western: $P=0.176$; eastern: $P=0.404$ ).

A correlation analysis revealed a significant positive relation between geographic and genetic distances of the samples $(r=0.39$; Mantel-test: $P<0.05$; see Figure 3$)$. The resulting $r^{2}$ of 0.15 indicates that $15 \%$ of the total genetic differentiation between populations is explained by their geographical distances. Spatial autocorrelation analysis supported isolation-by-distance: for two loci (6Pgdh, G6Pdh), Moran's I declined continuously with increasing geographical distance.

The mean number of alleles per locus declined from the southern samples (eg, western Hungary with 2.99 ( \pm 0.12 s.d.)) towards the northern ones (eg, Brandenburg with 2.16 ( \pm 0.25 s.d.)). We found a strong correlation between geographical latitude of the sample stations and the mean number of alleles per locus $(r=-0.88, P<$ 0.0001; see Figure 4). For the other tested parameters of

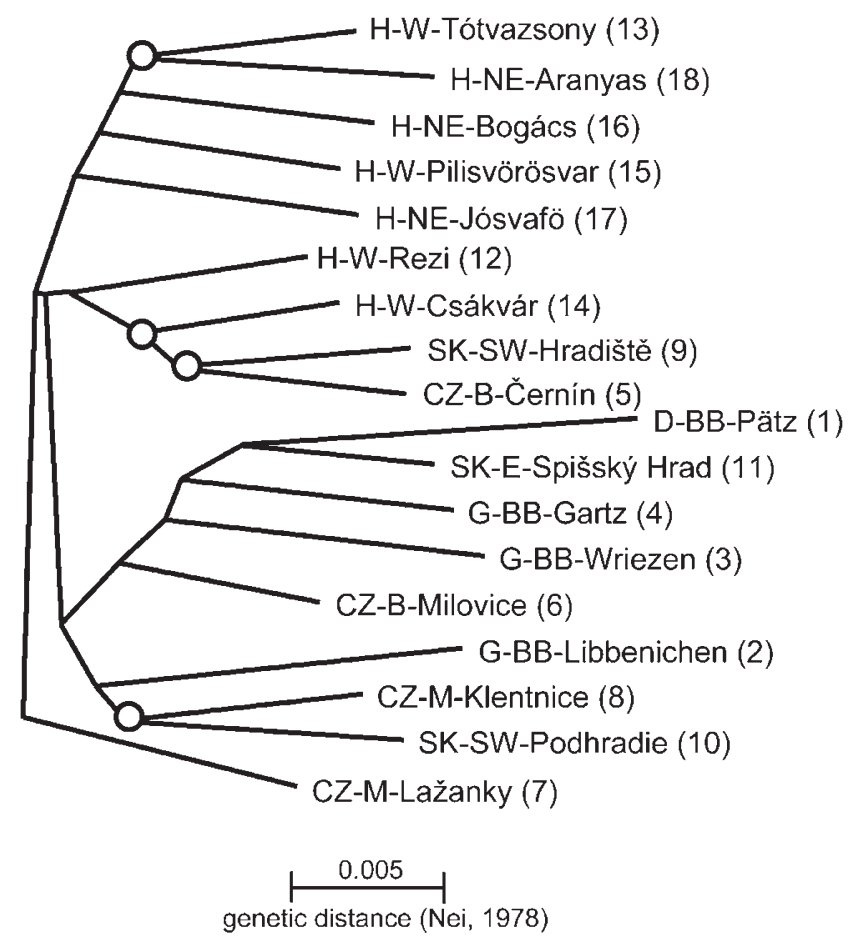

Figure 2 Neighbour-joining diagram of eastern European populations of Polyommatus coridon based on genetic distances (Nei, 1978). All nodes are significant on the $5 \%$ confidence level before Bonferroni correction. Those not significant after Bonferroni correction are marked with an open circle. The significance refers to $\mathrm{RxC}$ $\chi^{2}$ tests of homogeneity of allele frequencies. Abbreviations: First part: country; Second part: BB: Brandenburg, B: Bohemia, E: East, NE: North-East, M: Moravia, SW: South-West, W: West; Third part: name of sampling locality. The population numbers in parenthesis refer to those in Figure 1.

genetic diversity, we obtained weaker correlation (observed heterozygosity: $r=-0.61, P=0.007$; expected heterozygosity: $r=-0.59, P=0.010$; total percentage of polymorphic loci: $r=-0.54, P=0.020$; polymorphic loci at the 95\% level: $r=-0.18, P=0.466)$. The total variance was also highest in the western Hungarian populations cluster and lowest in the Brandenburg populations cluster (see Table 3).

The four samples from western Hungary had a significantly higher mean number of alleles per locus $(2.99 \pm$ 0.12 ) than the four from north-eastern Hungary and eastern Slovakia $(2.71 \pm 0.22)$ (U-test: $P=0.043)$. The two 


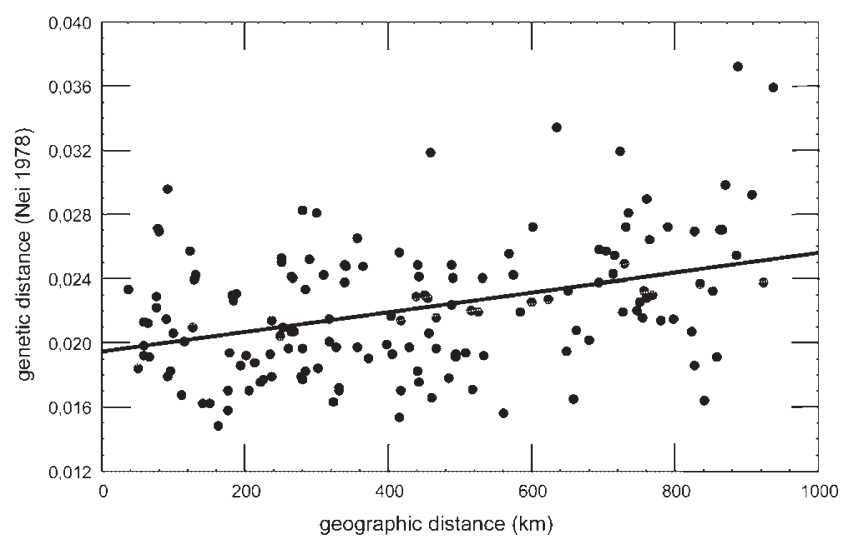

Figure 3 Relation between geographic and genetic distances of eastern European Polyommatus coridon populations (correlation analysis: $r=0.39$; Mantel-test: $P<0.05$ ).

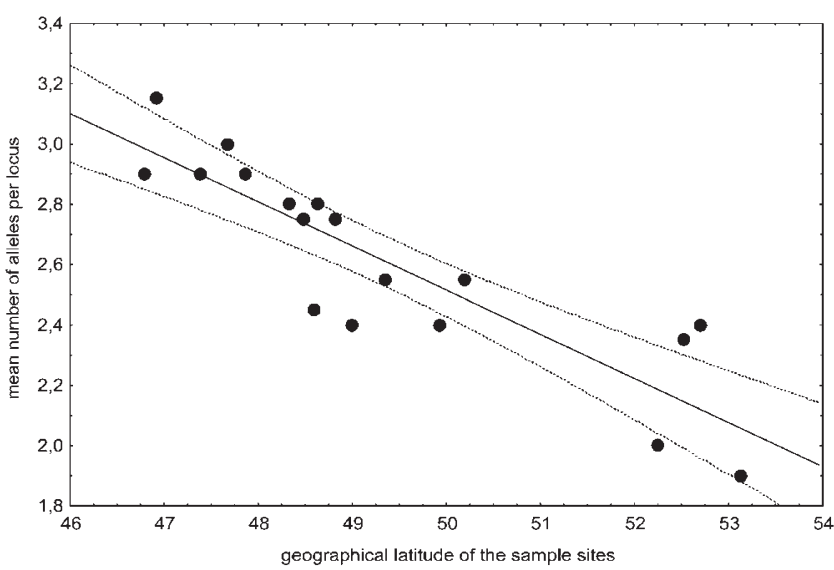

Figure 4 Correlation between geographical latitude of the sample site and the mean number of alleles of eastern European Polyommatus coridon $(r=-0.88, P<0.0001)$. The solid line shows the regression and the dotted lines the 95\% confidence interval.

Table 3 Genetic variance within and between populations and $F_{\mathrm{ST}}$ values for the five regional population clusters of eastern European Polyommatus coridon

\begin{tabular}{lllll}
\hline & \multicolumn{3}{c}{ Genetic variance } & \multirow{2}{*}{$F_{S T}$} \\
\cline { 2 - 4 } & Total & Between & Within & \\
\hline WH & $1.931^{* *}$ & $0.016^{*}$ & $1.915^{*}$ & $0.0083^{*}$ \\
NEH/ESK & $1.910^{* *}$ & $0.045^{* *}$ & $1.865^{* *}$ & $0.0237^{* *}$ \\
Mora/WSK & $1.919^{* *}$ & $0.041^{* *}$ & $1.878^{* *}$ & $0.0213^{* *}$ \\
Bohemia & $1.905^{* *}$ & $0.027^{*}$ & $1.878^{* *}$ & $0.0140^{* *}$ \\
Brandenburg & $1.705^{* *}$ & $0.080^{* *}$ & $1.625^{* *}$ & $0.0471^{* *}$ \\
\hline
\end{tabular}

Abbreviations: between $=$ between populations; within $=$ within populations; $\mathrm{WH}=$ western Hungary; NEH/ESK = north-eastern Hungary and eastern Slovakia; Mora/WSK = Moravia and western Slovakia. ${ }^{*} P<0.005 ;{ }^{* *} P>0.0001$.

populations sampled in Bohemia showed a lower mean number of alleles $(2.48 \pm 0.11)$ than the four populations that originated from Moravia and western Slovakia (2.63 \pm 0.17 ) (U-test: $P=0.25$ ).

\section{Discussion}

Genetic variation within populations of $P$. coridon

In relation to other butterfly species, eastern European populations of $P$. coridon displayed a high level of genetic diversity. In other surveys on lepidoptera, in general, lower values were found. Thus, higher mean numbers of alleles were observed in only a very limited number of studies (eg, Sluss et al, 1978; Vandewoestijne et al, 1999). Also the other parameters reflecting genetic heterogeneity were higher than the average of other analysed butterfly species. For more detailed data see Graur (1985), Packer et al (1998) and Schmitt et al (2002).

\section{Genetic differentiation among populations}

The obtained $\mathrm{F}_{\mathrm{ST}}(0.028 \pm 0.005$ s.d. $)$ and the means of genetic distances (Nei, 1978) between the studied populations of $P$. coridon $(0.022 \pm 0.003$ s.d.) are average values for lepidopterans (cf. Emelianov et al, 1995). These two values were similar to western European $P$. coridon $\left(\mathrm{F}_{\mathrm{ST}}\right.$ : 0.021 , mean of genetic distance between populations: 0.020; Schmitt et al, 2002). Higher values for both parameters have been observed for species that include more than one subspecies, such as the Californian Coenonympha tullia assemblage $\left(\mathrm{F}_{\mathrm{ST}}\right.$ : 0.051, maximum genetic distance between genetic lineages: 0.034; Porter and Geiger, 1988), Euphydryas editha in the Great Basin and the Rocky Mountains $\left(\mathrm{F}_{\mathrm{ST}}: 0.209\right.$, genetic distance between the two major lineages: 0.033; Britten et al, 1995) and the two host races of Zeiraphera diniana $\left(\mathrm{F}_{\mathrm{ST}}\right.$ : 0.083 , maximum genetic distance between lineages: 0.04; Emelianov et al, 1995). In not subspecifically differentiated lepidopterans, the genetic distances were mostly smaller than in eastern populations of P. coridon (eg, Daly and Gregg, 1985; Rosenberg, 1989; Britten et al, 1994). $\mathrm{F}_{\mathrm{ST}}$ values were higher in species showing a more patchy distribution than P. coridon (eg, Speyeria nokomis apacheana within regions: 0.227 , Britten et al, 1994; Euphydryas gilettii: 0.375, Debinski, 1994; Parnassius phoebus: 0.225, Descimon, 1995; Melitaea didyma: 0.077, Johannesen et al, 1996). In migrating or widespread species, the $\mathrm{F}_{\mathrm{ST}}$ values were lower than in our study or similar (eg, Heliothis virescens: 0.002, Korman et al, 1993; Pieris napi napi: 0.023, Porter and Geiger, 1995; Helicoverpa armigera: 0.007, Nibouche et al, 1998; Aglais urticae: 0.030, Vandewoestijne et al, 1999). Summing up, the eastern $P$. coridon lineage had a relatively weak genetic differentiation considering the extensive sampling area and the patchiness of habitats. The high population density in suitable habitats might prevent a stronger differentiation among populations due to the lack of genetic bottlenecks, and thus the conservation of once acquired genetic compositions.

\section{Isolation-by-distance}

The geographical distance between populations contributed significantly to the genetic differentiation between eastern populations of $P$. coridon $\left(r^{2}=0.15\right)$. This is supported by the observed continuously decreasing spatial autocorrelation for two loci.

The degree of isolation-by-distance is similar to that found for Chazara briseis on local scale in Sachsen-Anhalt, eastern Germany (Johannesen et al, 1997). For seven populations of Euphydryas editha gunnisonensis in the Rocky Mountains, around 59\% of genetic differentiation could be explained by isolation-by-distance, while 11 
Euphydryas editha-populations from the Great Basin showed no significant relationship (Britten et al, 1995). In Pieris napi meridionalis, even $64 \%$ of the differentiation could be explained by this phenomenon (Geiger and Shapiro, 1992). Thus, the observed structure gauged by isolation-by-distance of eastern populations of $P$. coridon is not very pronounced in comparison with other taxa (cf. Peterson and Denno, 1998).

\section{Postglacial expansions}

The number of alleles per locus declined constantly from western Hungary towards north-eastern Germany, correlating strongly with the geographical latitude. Seventyeight percent of the decrease of alleles is explained by the geographical latitudes of the sample sites. We suggest that this is the result of a constant loss of alleles during the gradual and continuous postglacial colonisation of eastern Europe from an ice-age refugium in the Balkans. Most probably, this genetic erosion occurred mainly during the expansion because the number of colonisers in general is low while established populations of $P$. coridon generally have high population sizes.

A similar phenomenon was observed in the gallwasp Andricus quercuscalicis which expanded its distribution from south-eastern Europe to the British Isles during the last 400 years: the distance from the centre of dispersal explained $78.5 \%$ of the variance of the expected heterozygosity and $84.7 \%$ of the variance of the mean number of alleles (Stone and Sunnucks, 1993). Also other examples of genetic impoverishment during expansions are known (eg, Highton and Webster, 1976; Schwaegerle and Schaal, 1979; Johnson, 1988; Aßmann et al, 1994; Demesure et al, 1996; Dumolin-Lapègue et al, 1997), however, rates of genetic loss are mostly less continuous than in $P$. coridon and A. quercuscalicis.

While the highest numbers of alleles were found in western Hungary, this area might have been the first one of the studied regions to be reached by $P$. coridon. We suggest that western Hungary was colonised from the north-eastern edge of the glacial refugium via the Dinaric limestone mountains (see Figure 5, path 1). An immigration via the Iron Gap (passage of the Danube through the southern Carpathians (for their geographic location see Figure 5, 'IG') seems to be less probable: (1) The eastern part of the Carpathian Basin (especially the Transsylvanian region) offers unfavourable conditions for $P$. coridon because of soil conditions and other natural circumstances (Bálint, 1996). Nowadays, the species is scarce in that region, and also during the early Holocene a higher density of populations is unlikely due to the lack of extended limestone areas. Thus, rapid expansion through such a region seems unlikely. (2) On this route, (i) western Hungary and (ii) north-eastern Hungary/ eastern Slovakia were the same expansion distance from the refugium. However, these two regions differ significantly in their mean number of alleles. (3) Furthermore, morphometric analyses of wing patterns show a high degree of homogeneity of populations from the northwestern part of the Balkans to Hungary and further north to Brandenburg and Poland. Other Balkan populations show greater morphological heterogeneity (Schmitt, unpublished data).

The cluster analysis in the neighbour-joining phenogram revealed a differentiation into an eastern and a western group. This is supported by hierarchical variance

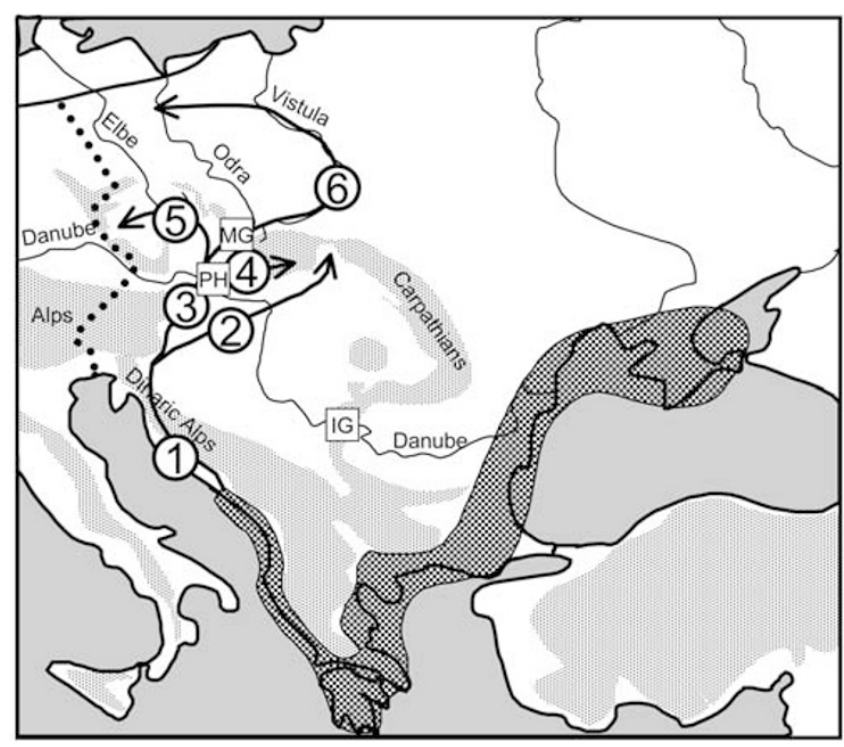

Figure 5 Postulated postglacial expansion routes of Polyommatus coridon. The assumed refugium is shown as a dark shaded field and assumed expansion corridors by arrows. Mountain regions are grey shaded. The dotted line represents the western border of the distribution range of the eastern genetic lineage. The solid line represents the northern distribution limit of the species. Abbreviations: IG: Iron Gap; PH: Porta Hungarica; MG: Moravian Gap; numbered expansion pathways are explained in the text.

analysis revealing significant deviation between these two groups. Within these groups, no hierarchical structure was detected. This suggests a split into two alternative expansion routes within eastern Europe (Figure 5): (1) from the western tip of Hungary following the Hungarian mountain chain to north-eastern Hungary and, later on, to eastern Slovakia (path 2) and (2) along the eastern Alps' foreland (path 3) and via the Porta Hungarica (for geographic location see Figure 5, ' $\mathrm{PH}^{\prime}$ ) to western Slovakia (path 4) and the Czech Republic (path 5).

The populations from Brandenburg show strong effects of genetic erosion presumable having taken place during the expansion process: $P$. coridon, possibly, passed the Moravian Gap in north-eastern Moravia (for geographic location see Figure 5, 'MG') to southern Poland where it reached the Vistula. Here, primary expansion might have followed the Vistula river system. Brandenburg might have been colonised from Poland by a westward migration via the Thorn-Eberswald glacial valley (Figure 5, path 6). An alternative colonisation of Brandenburg could have taken place along the river Odra. We assume this possibility less probable because of less favourable natural conditions in this region (eg, soils are too acid for the larval food plants). Similar expansion corridors were also suggested for Ponto-Mediterranean dragonfly species (Sternberg, 1998).

Postglacial expansion effects might also explain why Bohemian populations are less diverse than Moravian and western Slovakian ones, since the second region is closer to the glacial refugium. Therefore, Bohemian populations should be derived from those from Moravia and western Slovakia. Loss of genetic diversity might have occurred during the north-westwards expansion. To clarify this question definitively, more samples from the Czech Republic and western Slovakia will have to be analysed. 


\section{Acknowledgements}

We thank Andreas Gießl (Mainz) performing the electrophoresis of four populations, many colleagues for very friendly help in finding many of the sampling localities as well as Prof Dr Zoltán Varga (Debrecen, Hungary) and Dr Zdeněk Laštůvka (Brno, Czech Republic) for the excursions made together. Special thanks are due to Dr Paul Harding (Abbots Ripton, UK) for correcting our English. We also thank the Ministries of Environment in Prague, Bratislava and Budapest and the local authority in Potsdam for permissions to collect butterflies and work in several protected areas. We are also grateful to the Centre for Environmental Studies (ZFU) of the Johannes Gutenberg-University of Mainz and the Deutsche Forschungsgemeinschaft (DFG, grant number SE 506/6-1) for financial support and scholarship of the Graduiertenkolleg of the ZFU for T Schmitt.

\section{References}

Assmann T, Nolte O, Reuter H (1994). Postglacial colonization of middle Europe by Carabus auronitens as revealed by population genetics (Coleoptera, Carubidae). In: Desender K, Dufrêne M, Loreau M, Luff M, Maelfait J-P (eds) Carabid Beetles: Ecology and Evolution, Kluwer Academic Publishers: Dordrecht. pp 3-9.

Bálint Z (1996). A Kárpat-medence nappali lepkéi, I. MME: Budapest.

Britten HB, Brussard PF, Murphy DD, Austin GT (1994). Colony isolation and isozyme variability of the western seep fritillary, Speyeria nokomis apacheana (Nymphalidae), in the western Great Basin. Great Basin Naturalist, 54: 97-105.

Britten HB, Brussard PF, Murphy DD, Ehrlich PR (1995). A test for isolation-by-distance in Central Rocky Mountain and Great Basin populations of Edith's Checkerspot Butterfly (Euphydryas editha). J Hered 86: 204-210.

Buszko J (1997). Atlas rozmieszczenia motyli dziennych w Polsce (Lepidoptera: Papilionidae, Hesperiidae), Edycja Turpress: Torun.

Casgrain P, Legendre P (2001). The R package for multivariate and spatial analysis Version 4.0 (development release 3). Département de Sciences Biologiques, Université de Montréal, Montréal.

Daly JC, Gregg P (1985). Genetic variation in Heliothis in Australia: species identification and gene flow in the two pest species $H$. armigera (Hübner) and $H$. punctigera Wallengren (Lepidoptera: Noctuidae). Bul Entomol Res 75: 169-184.

Debinski DM (1994). Genetic diversity assessment in a metapopulation or the butterfly Euphydryas gilettii. Heredity 70: 25-30.

Demesure B, Comps B, Petit RJ (1996). Chloroplast DNA phylogeography of the common beech (Fagus sylvatica L) in Europe. Evolution 50, 2515-1520.

Descimon H (1995). La conservation des Parnassius en France: aspects zoogéographiques, écologiques, démographiques et génétiques, Editions OPIE, Volume 1, pp 1-54.

Dumolin-Lapègue S, Demesure B, Fineschi S, le Corre V, Petit RJ (1997). Phylogeographic structure of white oaks throughout the European continent. Genetics 146: 1475-1487.

Emelianov I, Mallet J, Baltensweiler W (1995). Genetic differentiation in Zeiraphera diniana (Lepidoptera: Tortricidae, the larch budmoth): polymorphism, host races or sibling species? Heredity 75: 416-424.

Felsenstein J (1993). PHYLIP (Phylogeny Inference Package) Ver. 3.5.c. Department of Genetics, University of Washington, Seattle, Washington.

Geiger H, Shapiro AM (1992). Genetics, systematics and evolution of holarctic Pieris napi species group populations (Lepidoptera, Pieridae). Zeitschr Zool System Evolutionsf 30: 100-122.

Graur D (1985). Gene diversity in Hymenoptera. Evolution 39: 190-199.
Hebert PDN, Beaton MJ (1993). Methodologies for allozyme analysis using cellulose acetat electrophoresis, Helena Laboratories: Beaumont, TX.

Hesselbarth G, Oorschot Hv, Wagener S (1995). Die Tagfalter der Türkei, Selbstverlag Sigbert Wagener: Bocholt.

Hewitt GM (1996). Some genetic consequences of ice ages, and their role in divergence and speciation. Biol J Linn Soc 58: 247-276.

Hewitt GM (1999). Post-glacial re-colonization of European biota. Biol J Linn Soc 68: 87-112.

Highton R, Webster TP (1976). Geographic protein variation and divergence in populations of the salamander Plethodon cinereus. Evolution 30: 33-45.

Johannesen J, Veith M, Seitz A (1996). Population genetic structure of the butterfly Melitaea didyma (Nymphalidae) along a northern distribution range border. Mol Ecol 5: 259-267.

Johannesen J, Schwing U, Seufert W, Seitz A, Veith M (1997). Analysis of gene flow and habitat patch network for Chazara briseis (Lepidoptera: Satyridae) in an agricultural landscape. Biochem Syst Ecol 25: 419-427.

Johnson MS (1988). Founder effects and geographic variation in the land snail Theba pisana. J Hered 61: 133-142.

Korman AK, Mallet J, Goodenough JL, Graves JB, Hayes JL, Hendricks DE et al (1993). Population structure in Heliothis virescens (Lepidoptera: Noctuidae): an estimation of gene flow. Ann Entomol Soc Am 86: 182-188.

Korschunov J, Gorbunov P (1995). Dnevnye Babotschki Asiatskoij Tschasti Roussii. Spravotschnik: Jekaterinburg.

Lelièvre T (1992). Phylogenie des Polyommatinae et structure génétique de six espèces du genre Lysandra, HEMMING (Lépidoptères Lycaenidae). PhD Thesis, Université de Provence.

Lesse H de (1969). Les nombre de chromosomes dans le groupe de Lysandra coridon [Lep. Lycaenidae]. Ann Soc Entomol France (n.s.) 5: 469-522.

Louis EJ, Dempster ER (1987). An exact test for Hardy-Weinberg and multiple alleles. Biometrics 43: 805-811.

Mantel N (1967). The detection of disease clustering and a generalized regression approach. Cancer Res 27: 209-220.

Marchi A, Addis G, Hermosa VE, Crnjar R (1996). Genetic divergence and evolution of Polyommatus coridon gennargenti (Lepidoptera, Lycaenidae) in Sardinia. Heredity 77: 16-22.

Mensi P, Lattes A, Salvidio S, Baletto E (1988). Taxonomy, evolutionary biology and biogeography of South West European Polyommatus coridon (Lepidoptera: Lycaenidae). Zool J Linn Soc 93: 259-271.

Nei M (1978). Estimation of average heterozygosity and genetic distance from a small number of individuals. Genetics 89: 583-590.

Nibouche S, Buès R, Toubon J-F, Poitout S (1998). Allozyme polymorphism in the cotton bollworm Helicoverpa armigera (Lepidoptera: Noctuidae): comparision of African and European populations. Heredity 80: 438-445.

Packer L, Taylor JS, Savignano DA, Bleser CA, Lane CP, Sommers LA (1998). Population biology of an endangered butterfly, Lycaeides melissa samuelis (Lepidoptera; Lycaenidae): genetic variation, gene flow, and taxonomic status. Can J Zool 76: 320-329.

Pamperis L (1997). The Butterflies of Greece, Bastas-Plessas Publications.

Peterson MA, Denno RF (1998). The influence of dispersal and diet breadth on patterns of genetic isolation by distance in phytophagous insects. Am Natural 152: 428-446.

Porter AH, Geiger H (1988). Genetic and phenotypic population structure of the Coenonympha tullia complex (Lepidoptera: Nymphalidae: Satyrinae) in California: no evidence for species boundaries. Can J Zool 66: 2751-2765.

Porter AH, Geiger H (1995). Limitations to the inference of gene flow at regional geographioc scales - an example from the Pieris napi group (Lepidoptera: Pieridae) in Europe. Biol J Linn Soc 54: 329-348. 
Raymond M, Rousset F (1995a). An exact test for population differentiation. Evolution 49: 1280-1283.

Raymond M, Rousset F (1995b). Genepop (V. 1.2): A population genetics software for exact tests and ecumenicism. J Hered $\mathbf{8 6}$ : 248-249.

Reinhardt R (1983). Beiträge zur Insektenfauna der DDR - Lepidoptera - Rhopalocera et Hesperiidae - II Nemeobiidae Nymphalidae. Entomol Nachr Ber Supplement 2.

Richardson BJ, Baverstock PR, Adams M (1986). Allozyme Electrophoresis. A Handbook for Animal Systematics and Population Studies, Academic Press: San Diego.

Rosenberg RH (1989). Genetic differentiation among populations of Weidemeyer's admiral butterfly. Can J Zool 67: 2294-2300.

Saitou N, Nei M (1987). The neighbor-joining method: a new method for reconstructing phylogenetic trees. Mol Biol Evol 4: 406-425.

Schmitt T, Seitz A (2001). Allozyme variation in Polyommatus coridon (Lepidoptera: Lycaenidae): identification of ice-age refugia and reconstruction of post-glacial expansion. J Biogeography 28: 1129-1136.

Schmitt T, Seitz A (2001b). Intraspecific structuring of Polyommatus coridon (Lycaenidae) analysed by population genetic studies. Nota lepid 24: 53-63.

Schmitt T, Gießl A, Seitz A (2002). Postglacial colonisation of western Central Europe by Polyommatus coridon (Poda 1761) (Lepidoptera: Lycaenidae). Heredity 88: 26-34.

Schneider S, Roessli D, Excoffier L. (2000). Arlequin ver. 2.000 A software for population genetics data analysis. Anthropology, University of Genève.
Schwaegerle KE, Schaal BA (1979). Genetic variability and founder effect in the pitcher plant Sarracenia purpurea. Evolution 33: 1210-1218.

Siegismund HR (1993). G-Stat, ver. 3, Genetical statistical programs for the analysis of population data. The Arboretum, Royal Veterinary and Agricultural University, Horsholm, Denmark.

Sluss TP, Sluss ES, Graham HM, Dubois M (1978). Allozyme differences between Heliothis virescens and H. zea. Ann Entomol Soc Am 71: 191-195.

Sokal RR, Rohlf FJ (1995). Biometry, 3rd edn. W.H. Freeman: New York.

Sternberg K (1998). The postglacial colonization of Central Europe by dragonflies, with special reference to southwestern Germany (Insecta, Odonata). J Biogeography 25: 319-337.

Stone GN, Sunnucks P (1993). Genetic consequences of an invasion through a patchy environment - the cynipid gallwasp Andricus quercuscalicis (Hymenoptera: Cynipidae). Mol Ecol 2: 251-268.

Taberlet P, Fumagalli L, Wust-Saucy A-G, Cosson J-F (1998). Comparative phylogeography and postglacial colonization routes in Europe. Mol Ecol 7: 453-464.

Tolman T, Lewington R (1998). Die Tagfalter Europas und Nordwestafrikas, Franckh-Kosmos, Stuttgart.

Vandewoestijne S, Nève G, M Baguette (1999). Spatial and temporal population genetic structure of the butterfly Aglais urticae L. (Lepidoptera, Nymphalidae). Mol Ecol 8: 1539-1543.

Weir BS (1991). Genetic Data Analysis, Sinauer, Sunderland, MA.

Weir BS, Cockerham CC (1984). Estimating F-statistics for the analysis of population structure. Evolution 38: 1358-1370. 